DOE/EA-1013

ENVIRONMENTAL ASSESSMENT

\title{
THE PROPOSED DIAGNOSTIC INSTRUMENTATION AND \\ ANALYSIS LABORATORY MISSISSIPPI STATE UNIVERSITY
}

\section{PREPARED BY
U.S. Department of Energy, Chicago Operations Office Programs and Facilities Management Division

November 1994

\section{DISCLAIMER}

This report was prepared as an account of work sponsored by an agency of the United States Government. Neither the United States Government nor any agency thereof, nor any of their employees, makes any warranty, express or implied, or assumes any legal liability or responsibility for the accuracy, completeness, or usefulness of any information, apparatus, product, or process disclosed, or represents that its use would not infringe privately owned rights. Reference herein to any specific commercial product, process, or service by trade name, trademark, manufacturer, or otherwise does not necessarily constitute or imply its endorsement, recommendation, or favoring by the United States Government or any agency thereof. The views and opinions of authors expressed herein do not necessarily state or reflect those of the United States Government or any agency thereof. 


\section{DISCLAIMER}

Portions of this document may be illegible in electronic image products. Images are produced from the best available original document. 


\section{TABLE OF CONTENTS}

Section

Page

1.0 DOCUMENT SUMMARY . . . . . . . . . . . . . . . . . . 1

2.0 PURPOSE AND NEED FOR AGENCY ACTION . . . . . . . . . . . . . . 1

3.0 DESCRIPTION OF ALTERNATIVES INCLUDING THE PROPOSED ACTION . . . . . 2

3.1 Description of the Proposed Action . . . . . . . . . . . 2

3.2 Project Description ....................... 2

3.3 The No Action Alternative . . . . . . . . . . . . . . . 7

3.4 Site Alternative ......................... 7

4.0 AFFECTED ENVIRONMENT . . . . . . . . . . . . . . . . . 7

5.0 ENVIRONMENTAL CONSEQUENCES OF THE PROPOSED ACTION AND ALTERNATIVES 8

5.1 Construction Impacts ................... . 8

5.2 Operation Impacts ........................ 9

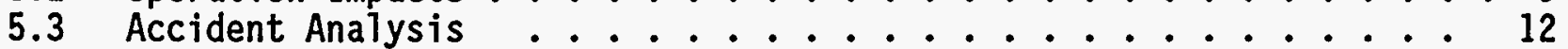

5.4 Cumulative Impacts .................... 12

5.5 Impacts of Alternatives .................. 13

5.6 Compliance with Regulations . . . . . . . . . . . . . 13

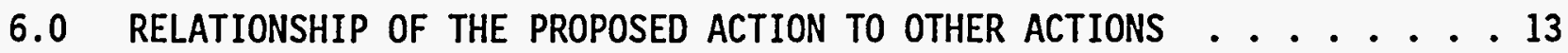

7.0 RELATIONSHIP OF THE PROPOSED ACTION TO ANY APPLICABLE FEDERAL,

STATE, REGIONAL, OR LOCAL LAND USE PLANS AND POLICIES LIKELY TO BE AFFECTED ............................. 13

8.0 LISTING OF AGENCIES AND PERSONS CONSULTED . . . . . . . . . . . 13

9.0 REFERENCES ........................ 14

APPENDIX A SUPPLEMENTAL DOCUMENTATION . . . . . . . . . . . . A A

Fiqure

LIST OF FIGURES

Figure 1 Proposed Site Location - Starkville Area . . . . . . . . . . 4

Figure 2 Area Map - Mississippi State University . . . . . . . . . 5

Figure 3 Proposed Site . . . . . . . . . . . . . . . . 6 


\subsection{DOCUMENT SUMMARY}

The Department of Energy (DOE) proposes to authorize Mississippi State University (MSU) to proceed with the detailed design, construction and equipping of the proposed Diagnostic Instrumentation and Analysis Laboratory (DIAL). DOE grant funds are available to the University for the limited purpose of performing preliminary studies, including analys is necessary to conduct this environmental assessment. The proposed facility would be located in the Mississippi Research and Technology Park, adjacent to the Mississippi Agriculture and Forestry Experiment Station campus in Starkville, Mississippi. Total project cost is estimated at $\$ 7,953,600$ (Reference (Ref) 1).

This proposed laboratory would be designed to conduct research into combustion devices related to waste management and environmental restoration that is of importance to industry and government. The proposed facility's role would be to develop diagnostic instrumentation capabilities in the area of combustion and related processes.

One alternative site was evaluated by the University. It was determined to be not feasible because of the absence of site access. Cost of construction of an access road was estimated at almost half a million dollars, and the additional funds were not available.

There would be no adverse construction impacts with respect to sensitive resources.

Under the no-action alternative, DOE would not authorize MSU to proceed with construction or any other action that would affect the environment or 1 imit alternatives. If MSU constructed the proposed DIAL with other funding, the impacts would be the same as those evaluated in the EA, although possibly delayed. If MSU determined to abandon the project, the construction impacts would not occur, and functions which were to be relocated from five campus locations to the proposed DIAL facility would continue to have the existing consequences.

The proposed DIAL construction would have no adverse impacts on sensitive resources.

The proposed DIAL would have no relationship to any other projects currently undergoing National Environmental Policy Act (NEPA) reviews and would be in accordance with all applicable land use plans.

Pollutant emissions from the proposed new facility are anticipated to be no more, and in some cases less, than current emissions generated by the research functions to be transferred to this facility from the MSU campus.

\subsection{PURPOSE AND NEED FOR AGENCY ACTION}

Senate Committee Report 101-000 accompanying the fiscal year 1991 Energy and Water Appropriations Act indicated Congress' desire that DOE provide funds to assist the proposed DIAL at MSU. DOE's purpose is to carry out this intent and to contribute to its own mission to promote research involving environmental 
restoration and waste management and energy alternatives and improvements.

The current facilities can neither provide adequate working space to allow for program growth nor for the onset of new research. There is a need to bring together staff, researchers and laboratories into one facility.

\subsection{DESCRIPTION OF ALTERNATIVES INCLUDING THE PROPOSED ACTION}

\subsection{Description of the Proposed Action}

The DOE proposes to authorize MSU to proceed with the detailed design, construction and equipping of the Diagnostic Instrumentation and Analysis Laboratory. As previously indicated, Senate Committee Report 101-000 accompanying the Fiscal Year 1991 Energy and Water Appropriations Act indicated that $\$ 3,976,800$ had been included in DOE's Fiscal Year 1991 appropriation to assist MSU with construction of the proposed DIAL facility. Grant \#DE-FG02-91CH-10479 was executed with the University in 1991 and grant funds are available to the University for the limited purpose of performing preliminary studies, including analys is necessary to conduct this environmental assessment. However, under the terms of the grant, the grantee may not initiate construction or take any other action that would affect the environment or limit alternatives until the DOE NEPA process has been completed and DOE has determined that such action should proceed.

The proposed DIAL would serve MSU's need to bring together staff, researchers and laboratories, now in five different locations with no space for expansion, into one facility. It would be an applied problem-oriented laboratory, and would not duplicate the mission of any other national laboratory.

The proposed laboratory would address specific problems and needs associated with large-scale combustion devices that could be used for environmental restoration and waste management. The proposed facility's role would be to develop diagnostic instrumentation capabilities in the area of combustion and related processes suitable for practical environments of particular interest to industrial and governmental agencies.

\subsection{Project Description}

\subsubsection{Construction Activities}

Construction of the proposed DIAL would begin as soon as a11 NEPA requirements have been satisfied. Construction is expected to take 18 months.

The building would be a four-story concrete frame structure with a masonry exterior, containing a total of 60,000 square feet, allocated as: 1) 19,000 square feet for administrative/staff; 2) 10,000 square feet for classrooms/meeting rooms/conference areas; 3) 18,000 square feet for laboratories; and 4) 13,000 square feet for Combustion Research 1aboratories.

Special requirements would include provisions for storage of combustion gases and fuel oil; power for computers, lasers, and related electronic equipment; cooling towers for high-temperature combustion test facilities; high bay areas for 
construction, testing, and calibration of mobile instrument 1aboratories; and interconnects for computer and communication systems between offices, 1aboratories, and campus and off-campus facilities. All gases and fuel would be stored in above-ground storage tanks in a limited-access area (Ref 1 ).

Figure 1 is a map of Starkville, Mississippi showing the location of Mississippi State University in relation to the town. Mississippi Research and Development Park, the site of the proposed DIAL facility, is shown at the northwest end of the campus. The campus extends to the north of Route 82 , so that the site is adjacent to the campus.

Figure 2 shows the site in relation to the campus as a perspective drawing. Current research activities which are to be relocated to the proposed DIAL, are currently housed in the following buildings shown on the figures:

- 19 Butler Hall

- 32 Hilbun Hall

- 75 Ethridge Chemical Engineering Building

- 78 Patterson Engineering Building

- 83 Simrail Electrical Engineering Building

There are no specific reuse plans for spaces to be vacated in these buildings. In general, they will be used to relieve overcrowding at research facilities remaining in the respective buildings.

Figure 3 is a local area map of the Mississippi Research and Technology Park showing the proposed DIAL site in relation to park landscaping and access roads.

Electric, gas, sewer, and water utility services currently exist under the road adjacent to the proposed building site and would be interconnected as between the campus and the DIAL site. They would be extended to the new structure as required. ATl existing university utility systems have adequate capacity to serve the proposed DIAL facility. The proposed supplier would be the Tennessee Valley Authority through the city of Starkville Power Company. Total project cost is estimated to be $\$ 7,953,600$ (Ref 1 ).

The proposed DIAL facility would have a natural draft cast iron sectional boiler system fueled by natural gas at a rate of approximately 6000 therms per year. (See section 5.2.7.2 for emissions estimate.)

The geographical relationship between the proposed DIAL site and the campus can be characterized as integrated, as they are adjacent, and there will be pedestrian, bicycle, and automotive access between the site and the campus. The furthest distance to a facility on campus likely to generate faculty, researcher and student movement is approximately 1.5 miles.

\subsubsection{Operation Activities}

The proposed DIAL Facility would be a laboratory that would provide the unique spaces required to bring a multi-disciplinary faculty, staff, and students of scattered organization together in a concerted effort to execute the research and prototype testing programs, the DOE's assigned technology transfer mission, and 


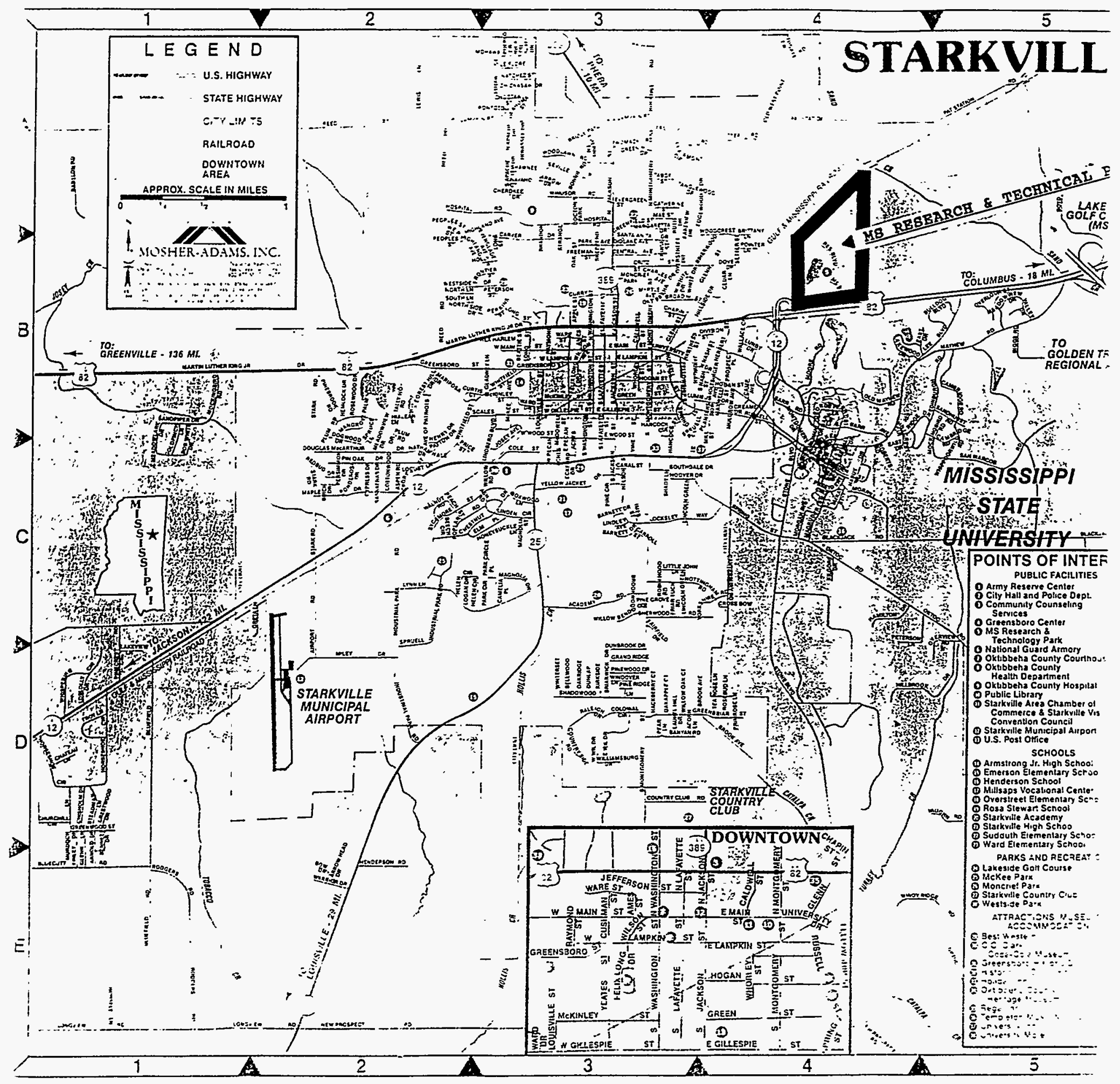

FIGURE 1. PROPOSED BITE LOCATION 


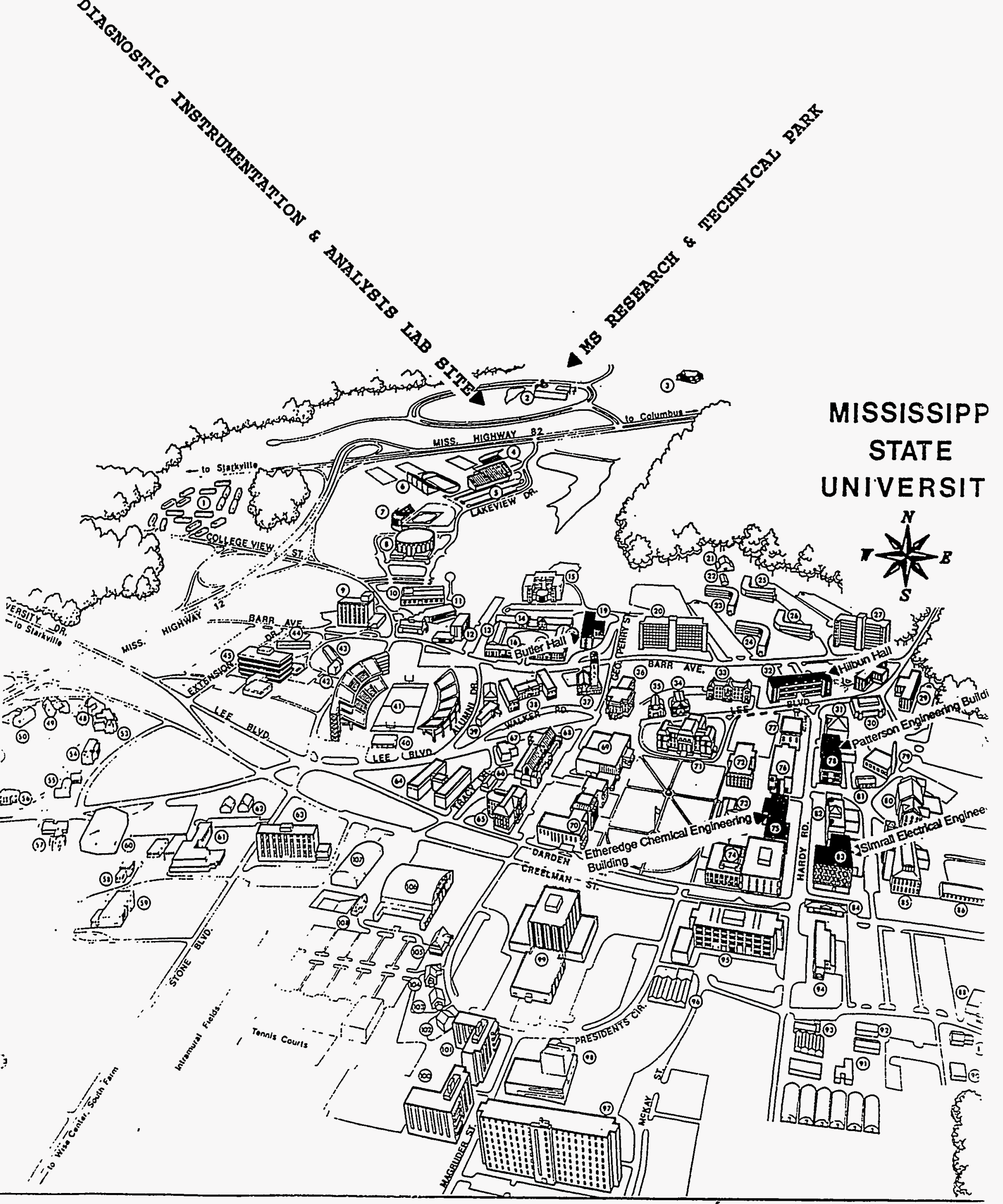




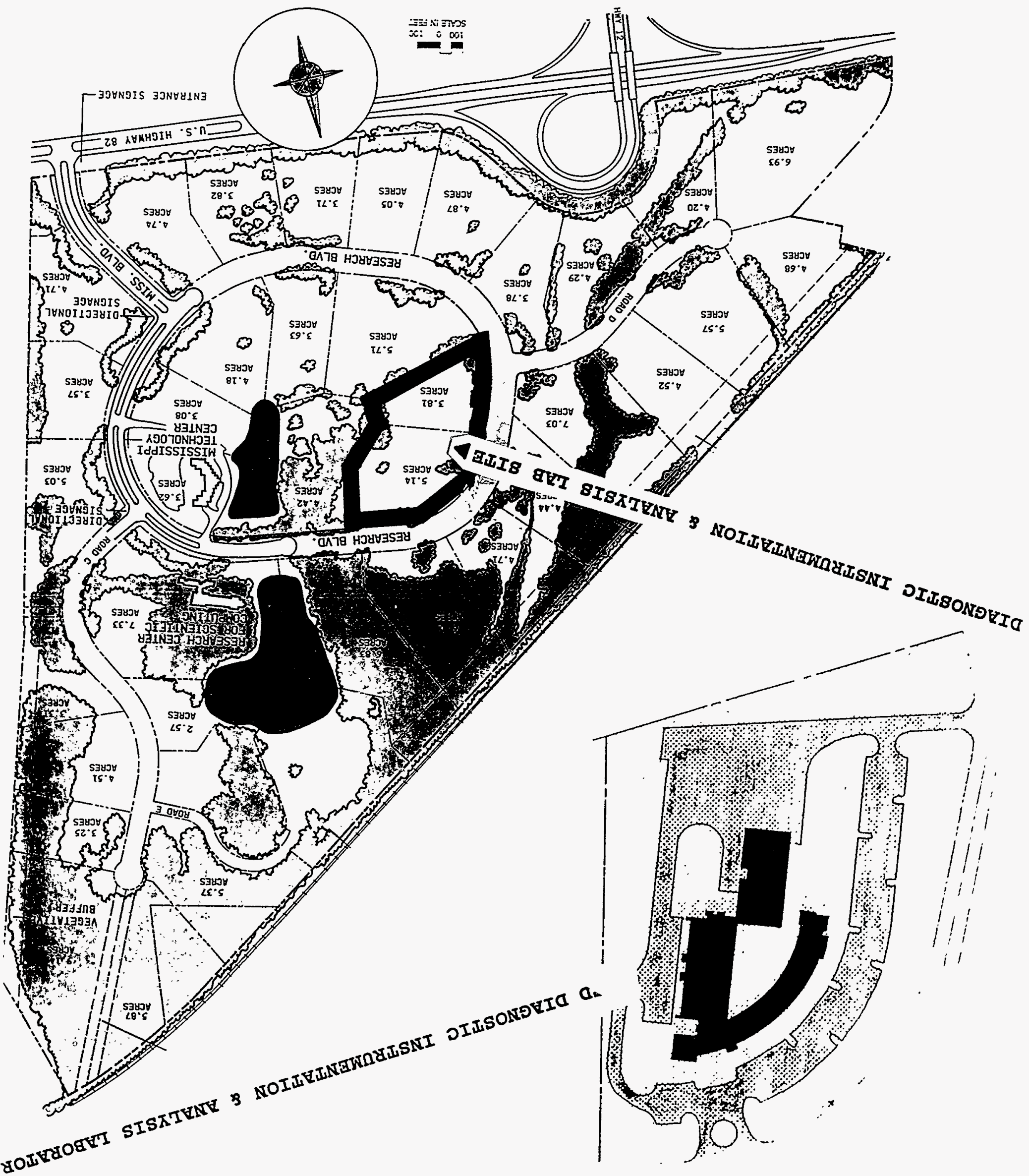


the related engineering and science education programs.

\subsection{The No Action Alternative}

Under the no action alternative, DOE would not authorize MSU to proceed with construction or any other action that would affect the environment or $1 \mathrm{imit}$ alternatives. Current operations would continue under existing management practices and overcrowded conditions. MSU would not proceed with the project in the absence of the Federal grant, as alternative funding is not available.

\subsection{Site Alternative}

One alternative sites was evaluated by MSU for the proposed DIAL facility. The alternative site is located on University property that is presently undeveloped. The site is located on a hill with a thin soil layer covering the underlying Selma chalk formation. The alternative site was determined to be unreasonable by the DIAL project manager and the University administration, due to lack of access. There is no access road, and although a road to this site is planned, there is no additional money to construct such access in the near future. The estimated cost for this access road was approximately $\$ 500,000$. (Ref 9).

While this alternative site has not been studied in detail it would appear to offer approximately equivalent environmental impacts, although the thin soil at that site would likely increase the effects of erosion.

\subsection{AFFECTED ENVIRONMENT}

The proposed site for the DIAL facility is a rural area located in the Mississippi Research and Technology Park, adjacent to the Mississippi Agricultural and Forestry Experiment Station campus in Starkville, MS. The 222acre Park is under the direction of the Oktibbeha County Economic Development Authority. Strict covenants, including architectural and landscaping provisions, performance standards, and 1 and use restrictions, ensure that high standards would be maintained by projects located in the Park.

The surrounding area will eventually be occupied by a variety of research facilities and other special high technology buildings.

The proposed DIAL site, containing 8.05 acres, is slightly sloped with a variance of approximately 35 feet. The proposed site is currently grassy, with a few trees and shrubs. The plan would be to locate the proposed laboratory on a clear area in the center of the acreage. The proposed site has not been subject to any prior contamination and any excavated materials would be free from chemical contamination (Ref 1$)$.

The area, including Starkville, has attainment status for all criteria pollutants.

There are no known historic/archeological resources associated with this proposed site (Ref 2). The proposed site does not host any federal/state-1isted or proposed protected species and is not part of or in the proximity of critical habitats (Ref 3 ). The proposed site does not 7 ie in a Department of Housing and 
Urban Development identified Special Flood Hazard area (FIA Map \#280277-0006-A). The proposed site is not a Wetland/Upland area (Ref $1,4,5$ ). The proposed site would not affect any State or National Park, Forest Preserve, Wild and Scenic Rivers, or National Trails. The proposed site does not contain any prime or unique farmland. The proposed site is not a special source of water nor does it sit on a sole source aquifer. (Ref 1$)$.

\subsection{ENVIRONMENTAL CONSEQUENCES OF THE PROPOSED ACTION AND ALTERNATIVES \\ 5.1 Construction Impacts}

\subsubsection{Environmenta11y Sensitive Resources}

There are no sensitive resources at or near the proposed site (see the description of the Affected Environment).

\subsubsection{Erosion/Run-off}

Five of the 8.05 acres on the proposed site would be disturbed by construction of the proposed laboratory. A "notice-of-intent" form (Ref 6) provides for a $\mathrm{pl}$ an for erosion control during construction, including use of hay bales and silt screening for erosion prevention. At the end of the construction phase, landscaping would include seeding and sodding the proposed site. Since the proposed site is in the Mississippi Research and Technology Park, all storm water runoff from that point on would be channeled into the Starkville storm sewer system, which already exists for the park (Ref 1, 5). A National Pollutant Discharge Elimination System (NPDES) permit would be required prior to initiation of construction. This would be issued by the state upon review and approval of the contractor's plan for erosion and runoff control.

\subsubsection{Demolition/Construction Waste Disposal}

The site is undeveloped, therefore there would be no demolition debris or contaminated soil involved in the construction of the proposed project. Some leveling of the land would be required, since there is a variance of 35 to 40 feet at extreme levels. Excavated material from site preparation would be used as clean fill on final grading of the building site, so there would be no offsite disposal. About 1,200 cubic yards of construction waste would be generated. This would consist of scrap wood, plaster/wallboard, concrete, wire and miscellaneous structural materials. There would be no asbestos waste generated (Ref 1). Waste would be disposed of at the local 1 andfill (which has adequate capacity) by the general contractor (Ref 1,9$)$.

\subsubsection{Air Quality Impacts}

Air quality impacts would be low level, intermittent and transient impacts resulting from the coming and going of trucks, operation of on-site machinery, and from dust created during construction.

\subsubsection{Noise}

Construction-related noise would be typical for a building project. Because 
there are no other buildings nearby, noise impact would not intrude on other activities. The nearest building is over 700 feet from the proposed site.

\subsubsection{Transportation Impacts}

The level of traffic generated by construction is not likely to exceed 30 trips per day at the peak activity level. The 8-acre site provides adequate space for all construction activities, including parking. The project would involve no relocation of persons or businesses.

\subsection{Operation Impacts}

\subsubsection{Domestic Haste}

The proposed DIAL organization is currently located in five separate buildings across the campus (Figure 2). The domestic waste generated in these buildings is part of the 3,000 tons of such waste generated each year by the University. Relocation of the organization to a single site is not expected to increase the annual amount of domestic waste, and it is projected that such amounts may decrease by at least 10\%. Haste from the proposed DIAL site would be handled by a waste management company through a contract with Mississippi State University. The company would be required to meet all existing University regulations. The waste would be disposed of in a Subtitle $D$ Landfill in the Golden Triangle area as mandated by Federal regulations effective October 1, 1993 (Ref 1).

The University has initiated a waste reduction program using programs of recycling, composting, and waste minimization education. Significant savings have already been achieved, and a $20 \%$ or greater reduction of waste-to- 7 andfil1 is expected by 1994 . The proposed DIAL facility would begin operations with the new program in effect.

Experiments conducted at the proposed DIAL will generate some additional waste material qualifying for ordinary landfill disposal. This would consist of approximately 500 pounds per year of residues containing non-hazardous potassium seed material and slag from air quality control experiments involving coal combustion (See section 5.2.7.2 for a description of these experiments).

\subsubsection{Sanitary Waste}

The proposed DIAL complex would generate 150,000 gallons of sanitary waste per month, which would represent 1 ess than $0.5 \%$ of the 34 million gallons per month average flow to the Starkville Sanitation Department municipal treatment plant by the entire University system. The proposed DIAL facility waste would flow directly into the existing outlets at the site and then into the municipal treatment facility for treatment (Ref 1,9 ).

The above sanitary waste load would include approximately 6,000 gallons of quench water per month containing some potassium seed material and slag from air quality control experiments involving coal combustion. (See section 5.2.7.2 for a description of these experiments). 


\subsubsection{Hazardous Waste (Laboratory Chemical Waste)}

As a smal1-quantity generator of hazardous waste, MSU is subject to the requirements of the Resource Conservation and Recovery Act (RCRA) of 1976. A11 hazardous and toxic waste generated by MSU is disposed of in accordance with all applicable federal and state regulations and guidelines. All hazardous waste generated by MSU is collected by the MSU Hazardous Waste Office and disposed of in a RCRA-permitted treatment, storage and disposal facility. Hazardous waste presently generated by the laboratories under this program include organic dyes dissolved in either ethyl alcohol or methyl alcohol in the amount of approximately 20 gallons per year. This could increase to as much as 30 gallons per year, and would become a small addition to the Waste Flammable Liquids that were generated by the University in 1992, and would not impact the current classification of smal1-quantity generator held by the University. The waste would be placed in labelled jugs and collected by the MSU Hazardous Waste Office for disposal in accordance with existing procedures (Ref 7).

\subsubsection{Biological/Medical Waste}

There would be no biological and/or medical waste produced by the proposed facility (Ref 1$)$.

\subsubsection{Radioactive and Mixed Hazardous/Radioactive Waste}

There are no activities $\mathrm{planned}$ for the proposed DIAL facility that would use radioactive materials and therefore, there would be no generation of radiological or mixed waste (Ref 1 ).

\subsubsection{Air Emissions}

There would not be anticipated increase in pollutant emissions from the research above that currently exists in scattered facilities across the campus where the work is presently being conducted. However, there would be a very smal1 increase from the gas-fired boiler to be located in the proposed facility.

\subsubsection{Criteria Pollutants}

\subsection{Emissions from DIAL Experiments}

The proposed DIAL operations would not result in an increase in criteria pollutants, since the consolidated activities would replace existing scattered activities. A small decrease (approximately 10\%) would be expected because of the increased sharing of equipment. The area, including Starkville, has attainment status for all criteria pollutants.

This proposed laboratory would be designed to conduct research into combustion devices related to waste management and environmental restoration. Tests of combustion devices would involve the burning of Number 1 fuel oil. In cases where coal combustion would be simulated, coal fly ash would be injected into the device. To simulate a Magneto Hydro Dynamic environment, potassium sulfate would also be injected. Scrubbers would be used in a11 combustion experiments. 
Annual air emissions from the typical projects or experiments conducted at the proposed DIAL would be as follows:

\begin{tabular}{||l|c|}
\hline \multicolumn{1}{|c|}{ EMISSION } & POUNDS PER YEAR \\
\hline \hline Carbon monoxide & 0 \\
\hline Particulates & 63 \\
\hline Nitrous oxides & 90 \\
\hline Carbon dioxide & 23,630 \\
\hline Sulphur dioxide & 25 \\
\hline
\end{tabular}

It is anticipated that the use of updated facilities would most likely result in a net decrease in pollutant emissions compared to historical and current levels. The proposed DIAL has received a letter from the Mississippi Department of Environmental Quality Office of Pollution Control stating that after a site visit, the Department has determined that the proposed DIAL would be exempt from a Clean Air Act permit at the present rate of output (Ref 8 ).

\subsection{Emissions from the proposed DIAL Boiler System}

The proposed DIAL facility's heating system would be a natural draft cast iron sectional boiler system fueled by natural gas at a rate of approximately 6000 therms per year. This system is estimated to produce the following annual emissions:

\begin{tabular}{||l||c||}
\hline \multicolumn{1}{|c|}{ EMISSION } & POUNDS PER YEAR \\
\hline \hline Carbon monoxide & 160 \\
\hline Particulates & negligible \\
\hline Nitrous oxides & 32 \\
\hline Carbon dioxide & 55,000 \\
\hline Sulphur dioxide & 136 \\
\hline
\end{tabular}

This level of emissions would have negligible effect on local air quality.

\subsubsection{Other Toxic Compounds Released to the Air}

The only potential toxic compounds that would be released to the environment would be methyl alcohol and ethyl alcohol. Based on the quantities reported in Section 5.2.3, releases to the atmosphere, which would be a zero to negative increase over existing, would not approach threshold limit values according to the American Conference of Governmental Industrial (Ref 13). None of the toxic compounds reported in Section 5.2.3 have emission standards specified in the National Emission Standards for Hazardous Air Pollutants regulations. 


\subsubsection{Noise}

The water-cooling system and air compressors would be housed in an area of the proposed laboratory to minimize operational noise. Presently, this equipment for the existing activities is located in an alley between two of the organization's existing buildings and has no noise insulation.

\subsubsection{Socioeconomic Impacts}

The proposed DIAL project would result in approximately 64 positions of a total of 3,242 for the entire University. The proposed DIAL staff would represent about $\$ 2,527,000$ million in direct payro11, compared to a total MSU payroll of $\$ 47,137,241$ (Ref 10,11 ). Of the 64 proposed DIAL positions, approximately 15 of these would be new hires over a four year period.

\subsubsection{Transportation}

Traffic generated by the proposed facility would be in the order of 200-300 trips per day for commuting, service vehicles (including waste pickup), and access to and from other campus facilities. Given the rural location of proposed DIAL and the University, the low level of traffic and the clear adequacy of access roads to and from the campus, a formal quantitative study of traffic and circulation was not performed as part of $\mathrm{planning}$ for this project.

\subsection{Accident Analysis}

Risk and consequences of accidents during construction would be that of any normal construction site activity. During the last 13 years there have been no major accidents nor any near misses associated with activities in scattered locations on campus that would be combined in the proposed DIAL facility. There have been minor accidents such as cuts, bruises, abrasions, pulled muscles, etc., among personnel conducting activities at various sites. These accidents over the 13 years have only cost a total loss of less than one man month (Ref 9). Based on this record, it is expected that there would be no major accidents from the proposed DIAL's activities.

\subsection{Cumulative Impacts}

Activities at the proposed DIAL facility would be similar to the current, ongoing work at scattered research laboratories now operating on campus. Cumulative impacts are defined as "the environmental impact of the action when added to other past, present, and reasonably foreseeable future actions..." per Title 40 Code of Federal Regulations, Part 1508.7. No new activities are planned for the vacated spaces, as existing activities currently conducted under conditions of overcrowding would simply use the space to relieve crowding. Cumulative impacts have been considered in the context of each environmental impact discussed in this document, as well as in relation to the impact of the project as a whole. There is no evidence that any of these cumulative impacts would be significant in the NEPA sense of the term. 


\subsection{Impacts of Alternatives}

\subsubsection{No-Action}

No action by DOE would mean that MSU would be without a large amount of the funding required to construct and equip the proposed DIAL. Construction and operation of the proposed facility would likely not occur. If a decision was made by the University not to construct the proposed DIAL, the minor environmental impacts associated with construction would not occur, although another facility would likely be constructed at the site in the Research Park in the future. Current impacts of the campus functions which would have been relocated to the proposed DIAL would continue to occur, including noise, emissions, and safety impacts which would be reduced by the new facility.

\subsubsection{Site A7ternative}

One site alternative was considered as described in section 3.4. While this alternative site has not been studied in detail it would appear to offer approximately equivalent environmental impacts, although the thin soil at that site would likely increase the effects of erosion.

\subsection{Compliance with Regulations}

A building permit from the City of Starkville may be required, since the site for this proposed facility is within the city limits. The ruling for this permit would not be made until near the time of construction and actual purchase of the property.

A boiler permit would be required for construction and operation of the proposed DIAL boiler system.

The proposed DIAL site and the campus are contiguous, and the proposed DIAL would be covered under the University's existing hazardous waste management permits.

\subsection{RELATIONSHIP OF THE PROPOSED ACTION TO OTHER ACTIONS}

The proposed action is not related to other actions or to actions being considered under other NEPA reviews.

\subsection{RELATIONSHIP OF PROPOSED ACTION TO ANY APPLICABLE FEDERAL, STATE, REGIONAL OR LOCAL LAND USE PLANS AND POLICIES LIKELY TO BE AFFECTED}

There is no relationship of the proposed action to any applicable federal, state, regional or local land-use plans.

\subsection{LISTING OF AGENCIES AND PERSONS CONSULTED}

Persons from the following agencies have contributed to the information contained in this document:

Dan Cotton, District Biologist, Mississippi Department of Wildlife, Fisheries and Parks 
Michael E. Miller, Mobile District, Corps of Engineers

Roger Walker, Review and Compliance Officer, Mississippi Department of Archives and History, Historic Preservation Division

Janet Rafferty, Associate Professor, Cobb Institute of Archaeology

Lynn Martin, Air Permitting Branch, Department of Environmental Quality, State of Mississippi

\subsection{REFERENCES}

1. Environmental Report for the Diagnostic Instrumentation and Analysis Laboratory, Mississippi State University, April 26, 1993 prepared by Darlene H. Breaux, DIAL Project Management Coordinator, with inputs from DIAL engineering personnel

2. Mississippi Department of Archives and History, Historic Preservation Division, Roger G. Halker, Review and Compliance Officer, February 22, 1993

3. Mississippi Department of Wildl ife, Fisheries and Parks, Dan Cotton, District Biologist, November 3, 1992

4. Mobile District Corps of Engineers, Michael E. Miller, Chief of Regulatory Branch, Operations Division, December 21, 1992

5. State of Mississippi Registered Professional Engineer Robert Anthony Green, June 26, 1992

6. Construction Notice of Intent (NOI) Darlene H. Breaux, Project Management Coordinator, Mississippi State University, April 13, 1993. NPDES Permit Number would be assigned by the State at the start of construction

7. Research Policy Series, Policy and Procedure Statement on Hazardous Waste at Mississippi State University, November 5, 1990

8. Mississippi Department of Environmental Quality, Lynn Martin, Air Permitting Branch, February 25, 1993

9. Additional information received from Darlene Breaux October 4, and October 8, 1993

10. Data received from Darlene Breaux November 12, 1993

11. Campbe11, Charles A., "Estimation of the Economic Impact of the Diagnostic Instrumentation and Analysis Laboratory at Mississippi State University in the Golden Triangle Area, MSUn April 1993

12. Data received from Darlene Breaux, including photos, brochures, and a hazardous waste report, February 1994 
13. American Conference of Governmental Industrial Hygienists, Threshold Limit Values for Chemical Substances and Physical Agents and Biological Exposure Indices, 1993-94 
APPENDIX A

SUPPLEMENTAL DOCUMENTATION

A-1 


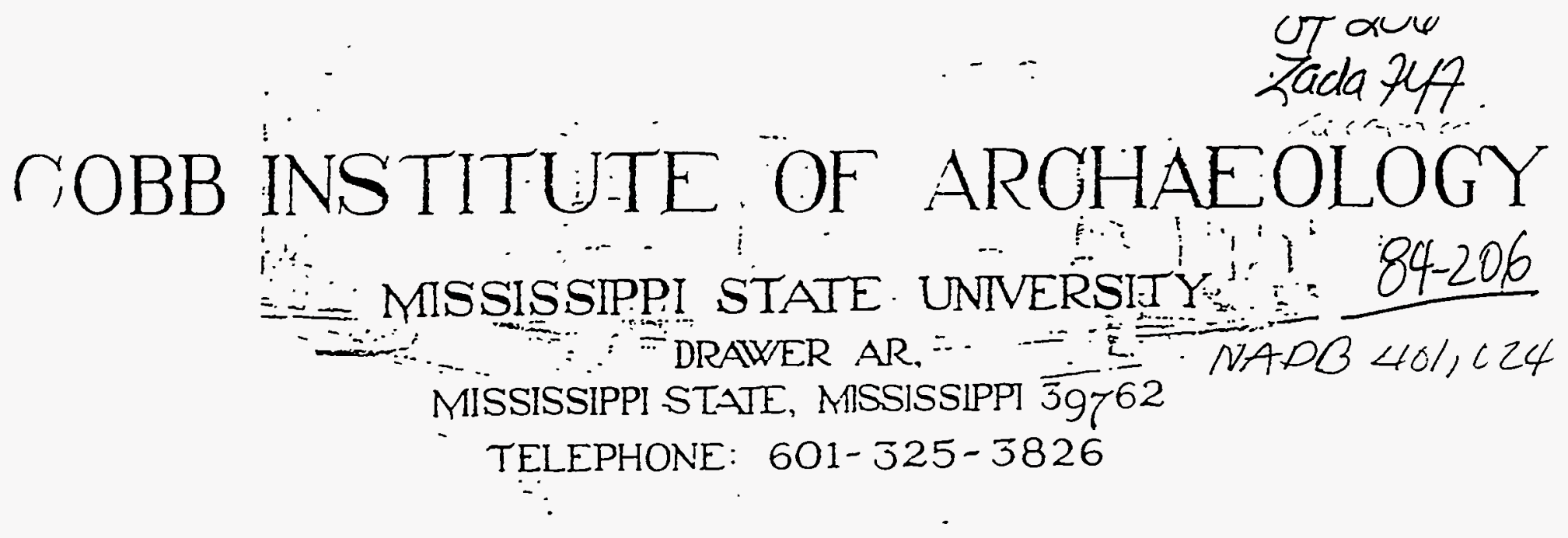

Octoder 9, 1984

John H. Peterson, Jr., Director

Cobb Institute of Archaeology

Campus

Dear Dr. Peterson,

A cultural resources survey has been done of the land that is to be exchanged by Mississippi State University for use by the Oktibbeha County Industrial Development Foundation Project. Only one site, Site $\$ 1$, was Found on the property, in the area indicated on the enclosed maps. Another site, W Site $\# 2$, is directly adjacent to the property on the northeast side. An analysis of the artifacts from these sites is appended.

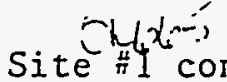
assign it definitely to a cultural period. However, the lack of pottery at the site and the presence of a midsection of a large biface indicates that the site probably contains an Archaic component. Site $" 2$ is assignable to the late prehistoric-protohistoric period on the basis of the types of pottery found there. iveither site appears to contain unique data and both have been disturbed to an unknown extent by cultivation. However, since neither site was shovel-tested or otherwise tested below the surface, it is recommended that they be avoided during construction if possible. If avoidance is not possible, it is recommended that an archaeologist be on hand when dirt is moved in the vicinity of the sices in order to determine the significance of any intact sub-surface deposits that may be present.
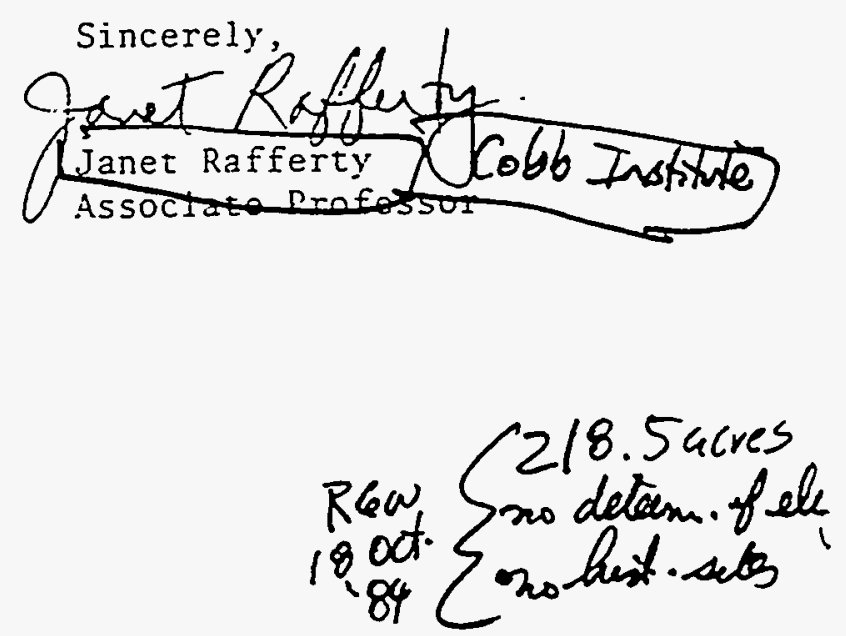


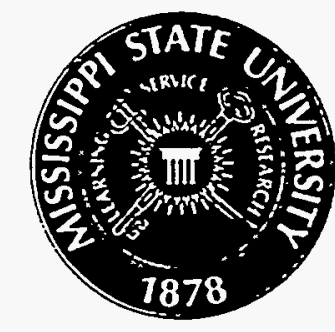

Diagnostic Instrumentation and Analysis Laboratory

26 June 1992

Mr. Jerry Nelson

Chicago Field Office

NEPA Compliance Office

9800 South Cass Avenue

Argonne, IL 60439

Dear Mr. Nelson:

This letter is to certify that I have examined the Flood Insurance Rate Map (FIRM) provided by the Federal Emergency Management Agency and have determined the proposed site for the Diagnostic Instrumentation and Analysis Laboratory (DIAL) Building in the Mississippi Research and Technology Park in Starkville, Oktibbeha County, Mississippi, is not located in a flood hazard zone. The proposed building site is located on FIRM Community Panel Number 280277 0006A, dated February 17, 1978.

Sincerely,

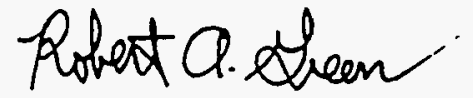

Robert A. Green, P.E.

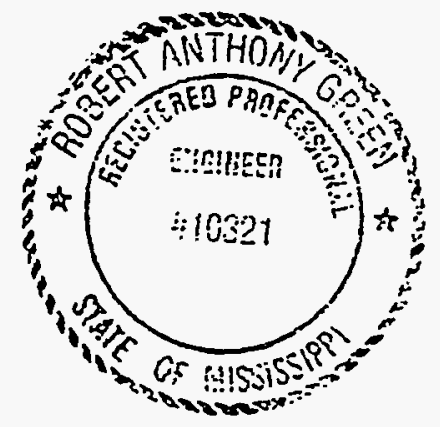




\section{MISSISSIPPI DEPARTMENT OF WILDLIFE, FISHERIES AND PARKS

\author{
P. O. Box 152 \\ Macon, Mississippi 39341
}

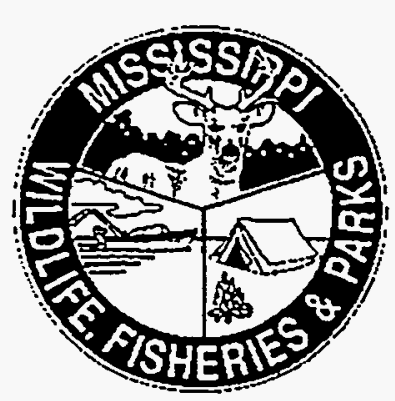

November 3, 1992

Mr. Jerry Nelson

NEPA Compliance Officer

DOE, Chicago Field Office

9800 South Cess Avenue

Argonne, Illinois 60439

Re: Proposed Building Site Inspection

Dear Mr. Nelson:

I have inspected the proposed building site for the Diagnostic Instrumentation and Analysis Laboratory at Mississippi State University. The site is located in the Mississippi State Research and Technology Park.

I found no evidence of any endangered wildlife species being present on the site, and no wetlands will be affected by the construction of the proposed building.

If I can be of further assistance please feel free to contact me.

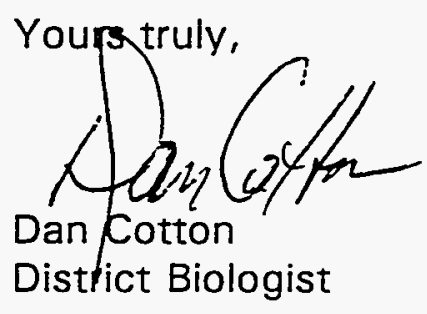




\section{Mississippi Department of Archives and History}

Historic Preservation Division - Post Oitice Box 5il • lackson. Mlississ!pp 39205.05i1

Telephone 601-359-6940

December 11,1992

Ms. Darlene H. Breaux

Miss. State University

P. 0. Drawer MM

Miss. State, MS 39762-5932

Dear Ms. Breaux:

RE: Diagnostic Instrumentation and Analysis Laboratory (DIAL) on the Starkville campus of Mississippi state University, Oktibbeha County.

Thank you for your phone call today, in which you notified me that the above mentioned project area has been moved. In this regard, you requested revised comments from those offered in my November 19, 1992 , letter.

Specifically, the project area falls within that area surveyed in cultural resource survey report \#84-206 rather than 非1-280. Report 非4-206 uncovered two archaeological sites, $22-0 \mathrm{~K}-664$ in sec. 25 and site $22-0 \mathrm{~K}-665$ in sec. 35 . Since it is our understanding that the proposed project will be in sec. 36 , it is our opinion that no properties listed in or eligible for listing in the National Register of Historic Places will be affected. I have enclosed a copy of report \#84-206.

There remains a very remote possibility that unrecorded cultural resources may be encountered during construction. Should this occur, we would appreciate your contacting us immediately so that we may take appropriate steps under 36CFR800, part 11 , regarding our response within forty-eight hours. 
Ms. Darlene H. Beaux

December 14, 1992

Page Two

We appreciate your giving us the opportunity to comment. If we can be of assistance, please do not hesitate to contact this office at 359-6940.

Sincerely,

Roger D. Walker

Roger G. Walker

Review and Compliance officer

$\mathrm{RGW} / \mathrm{sjb}$

cc: Clearinghouse for Federal Programs 


\author{
DEPARTMENT OF THE ARMY \\ MOBILE DISTRICT, CORPS OF ENGINEERS \\ P.O. BOX 2288 \\ MOBILE. ALABAMA 36628-0001
}

December 21, 1992

REPLY TO

ATTENTION OF:

Regulatory Branch

SUBJECT: MSJ92-03207-D, Jurisdictional Determination proposed construction, Darlene Breaux

Ms. Darlene Breaux

Diagnostic Instrumentation and

Analysis Laboratory

Post Office Drawer MM

Mississippi State, Mississippi 39762

Dear Ms. Breaux:

Reference is made to your letter dated December 3, 1992 , requesting a jurisdictional determination for the proposed construction of a new facility for the Diagnostic

Instrumentation and Analysis Laboratory. Specifically, the site is located in section 36, Township 19 North, Range 14 East, Oktibbeha County, Mississippi.

An on-site inspection conducted on October 30,1992 revealed that a Department of the Army permit pursuant to Section 404 of the Clean water Act will not be required from our office for the proposed work. The site is a nonwetland/ upland area. It should be noted that the U.S. Army Corps of Engineers utilized the 1987 Wetland Delineation Manual for the above determination.

Please be advised that this jurisdictional determination reflects current policy and regulation and is valid for a period of three years from the date of this letter. If after the three-year period, this jurisdictional determination has not been specifically revalidated by the U.S. Army Corps of Engineers, it shall automatically expire.

This letter grants no property rights and does not obviate the necessity for you to obtain any other local, state, or Federal authorization that may be required for this activity.

Thank you for your cooperation with our permit program. If you have any questions concerning this matter, please 
contact Mr. Mike Holley of the Jurisdiction and Enforcement Section at (601) 327-2142.

Sincerely,

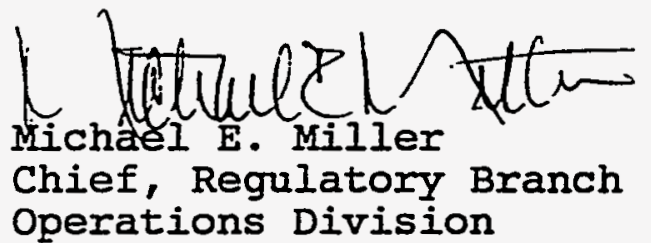




\section{Mississippi Department of Archives and History}

Historic Preservation Division - Post Office Box $5 \mathrm{r} 1$ - Jackson. Mississippi 39205.0571

Telepinone 601-359.6940

Eebruary 22, 1993

Ms. Darlene H. Breaux

Mississippi State University

P. O. Drawer MM

Mississippi State, MS 39762-5932

Dear Ms. Breaux:

RE: Diagnostic Instrumentation and Analysis Laboratory (DIAL) on the Starkville campus of Mississippi State University, Oktibbeha County

Dear Ms. Breaux:

Reference is made to our meeting today to review the current status for planning the above mentioned undertaking. My letter of December 11, 1992, had indicated the proposed project site to be in sec. 36 , but the finalized site plans indicate that it will be in sec. 35 , T19N, Rl4E.

Based on our review of the aforementioned finalized plans, it is our opinion that the project will have no effect on any properties listed in or eligible for listing in the National Register of Historic Places.

Thank you for your continued cooperation.

Sincerely,

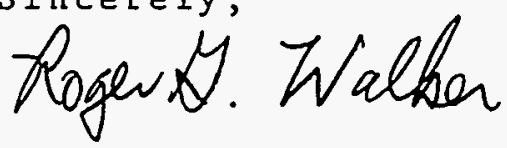

Roger G. Walker

Review and Compliance Officer

cc: Clearinghouse for Federal Programs 


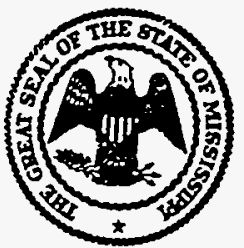

STATE OF MISSISSIPPI

DEPARTMENT OF ENVIRONMENTAL QUALITY

JAMES I. PALMER, IR.

EXECUTIVE DIRECTOR

Fcbruary 25. 1993

Ms. Dariene Breaux, Project Manager Coordinator

Diagnostic Instrumentation \& Analysis L...ahoralory

P.O. Drawer MM

Mississippi State MS 39762

Dcar Ms. Brcaux:

\section{Re: Coal Ash Test Facility}

A technical revicw of information on you facility inclicales that you are cxempt from permitting and no further action is required by you at this time.

If you plan any significant modification to your facility. please notify the Office of Pollution Control as soon as possible after the decision to make the modification. Such modification include a significant change in the ratc of opcration of any process or device at this location, and significant changes in the hours of opcrations, modification of the process itself or the addition of new devices or processes at this address. Such modifications may require that you firm obtain a permit prior to making these modifications.

Very truly yours.

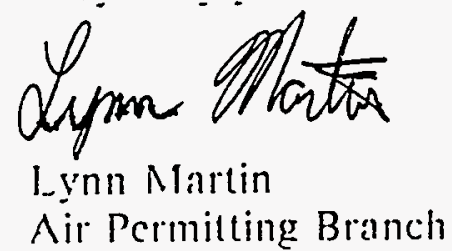

$L M: s r$ 


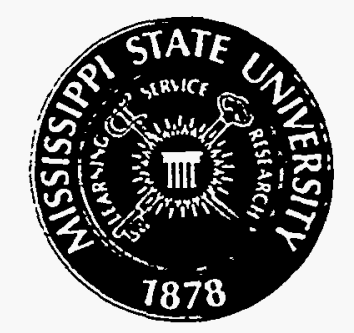

Diagnostic Instrumentation and Analysis Laboratory

April 13, 1993

Mr. Louis Lavallee

Chief of the Storm Water Division

State of MS Department of Environmental Quality

office of Pollution Control

P.O. Box 10385

Jackson, MS 39289-0385

Dear Mr. Lavallee:

Please find attached a construction notice of intent for coverage under construction storm water general NPDES permit. This notice has been filled by the architects under contract with Mississippi State University for the construction of the Diagnostic

Instrumentation and Analysis Laboratory (DIAL) and being filed by Darlene Breaux, Project Management coordinator, of DIAL. This notice of intent is being filed under state mandate and federal mandate as part of the completion of the National Environmental Protection Act survey for this construction site.

The site is located in the Mississippi Research \& Technology Park in starkville, MS. The legal description of the site is the East Half of the East Half of section 35, Township 19 North, Range 14 East, oktibbeha County, Mississippi, and contains 8.05 acres. The acreage that will be disturbed by construction of the laboratory will be approximately 5 acres. Attached to the notice of intent form is a plan for erosion control during construction. Since the site is in the Mississippi Research and Technology park, all stormwater runoff from that point on will be channeled into the starkvilie sewer system which is already existing in the Park. A copy of the 25-year storm Water Runoff Calculation is also attached.

If you should have any question, please call me at (601)325-7383. Thank you for your assistance.

Sincerely,

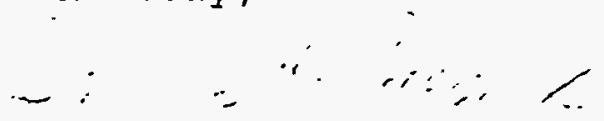

Darlene H. Breaux

project Management coorainator

CC: NEPA Report

enclosure 


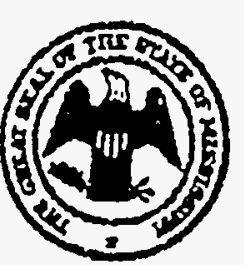

STATE OF MISSISSIPPI

DEPARTMENT OF ENVIRONMENTAL QUALITY

LMEE I. PALMER. IR.

EXECUTIVE DIRECTOR

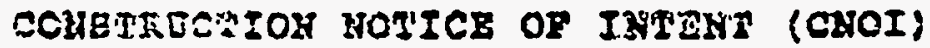

FOR COYEÄGE TNDBR COMBTROCTIOX STORA HATER

IEXERAL KTDES PZKUIT MER10

(Hunbar to be assignod by gEtate)

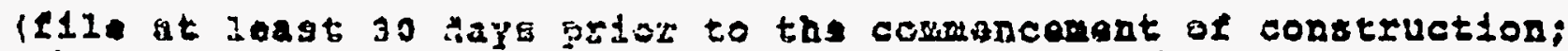

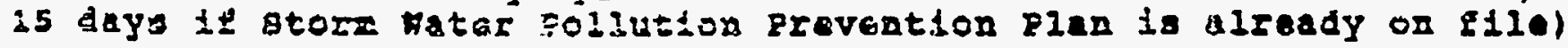

NAXE OF KPPLICANT:

Eley Associates/Architects P.A.

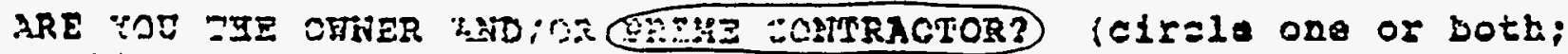

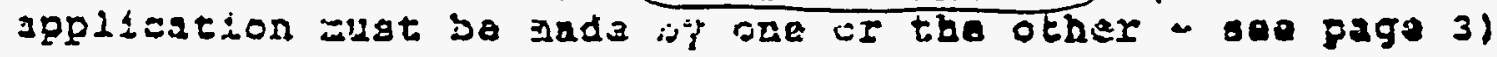

If HOT THE CNNER, NAHE iJE IHWER: DIAL - Mississippi State University

CONTACr Persog (12 Jthox "ilen applicant): Dr. Steve Shepard, Director DIAL

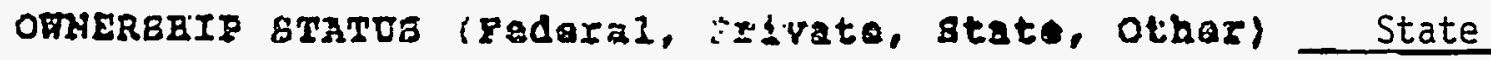

OWWER'B MAILIMG ADDFESE ANQ TELEEHONB MUMBER:

HOKBER AND BTREET (9. O, 30Z;: P. 0. Drawer MM

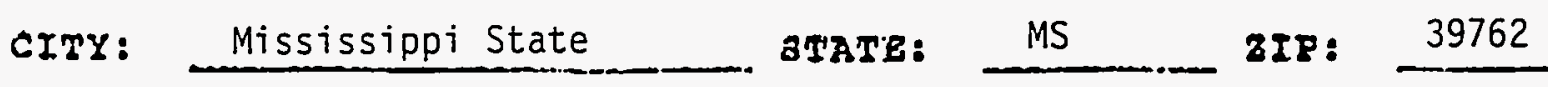

TELAPGONE HTHSER (THCTERE AREA CODE): (601) 325-2105

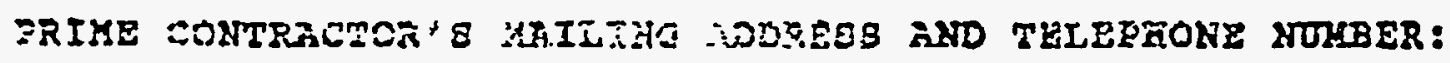

NUABER FHO ETREET (D. D: 418 East Capitol Street

cITy:

Jackson BTATE: MS ZIP: 39201

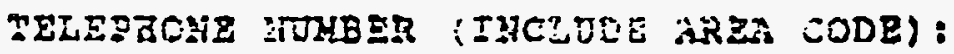
(601) $354-2572$

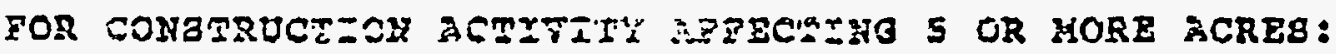

2ROJECr SRYE: Diagnostic instrumentation \& Analysis Laboratory Building

YROTECM ZCCATIOH: OAt: Starkville county Oktibbeha

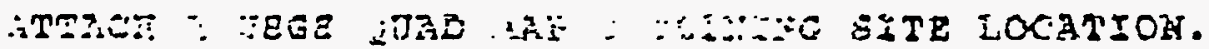

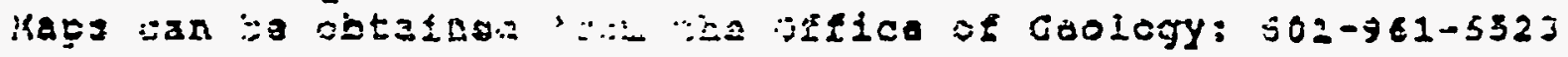

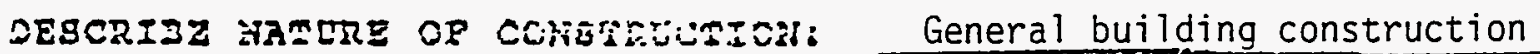
TOTAY ACREAGZ MEAT :IID :Z DISTTRBRD: $\quad 5$ acres 
ESTIMATED TIKETABI: (atsacb additlonal sbe日ts 1 nagded):

BTART DATE December 1993 COMPLETION DATE

July 1995

TYPB OP HATURAT BOIL ON EITE:

Silty Clay $\left( \pm 15^{\prime}\right.$ deep) over Selma Chalk

ESTIUATE RUNOPP COBEEICI SIFT:

0.35 (Pervious), 0.90 (Impervious)

NATURE OE PROPOBED FILE WATERIAL:

INCREASE IN IMPERVIOUR ACRRAGE:

non-plastic select sand-clay soil

3.404 acres

DOES ANY STORMRATER GO TৃO A KENTCIPAL STORM 8EFER?

Yes

If so, ist municipality:

City of Starkville

ATWACE \{AFTER SPRII 1, \$393\} GTORM HATER ROLLUTION PREVENTION PLAN (SWPYFi DESCRIBINO RLE SRDEION AND SEDIMENT CONTROL MEASUREE TO BE IHPLEKENTED DDRING LNC .AFTIR CONATRUCTION, AB REQUIRED IN TKE PERMIT.

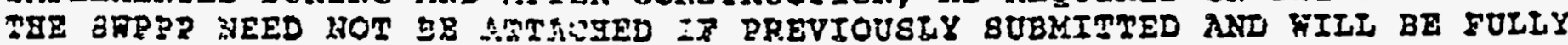

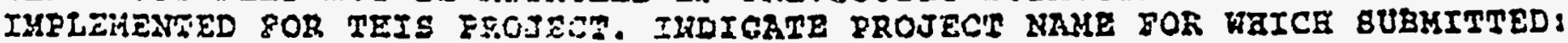

Diagnostic Instrumentation \& Analysis Laboratory Building

PERMIT COVERACE TOR BOFJOIF AKD TOPPING ITTE MAY BE NDEDED AND LUST BE AFEIIED FOR 3EEARATELY.

I certsty jader penzity $=2$ lak that this document and all attechments wero proparat undor ny airsctien or gupervigion in accordance with a system desigaed te asura that cualified porsonnel properly gatbered and ovaluatod tho information auonitted. Basad on my inguiry of the persen

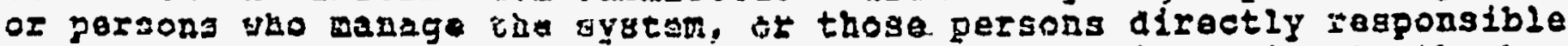

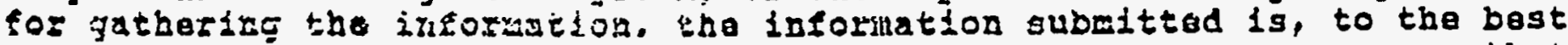
of ay htowledgo and tajist, cau, aceurate and complete. I am aware that

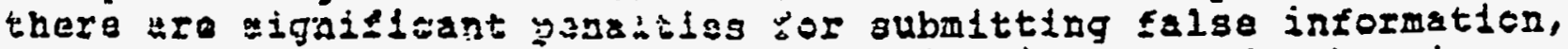

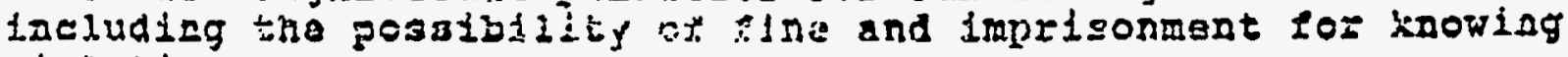
violatiass.

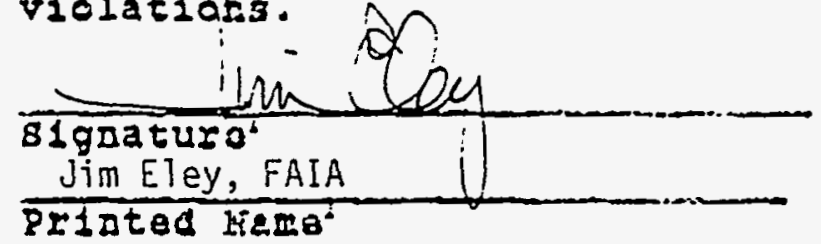

$\frac{3-31-93}{\text { ARTE 8IGNED }}$

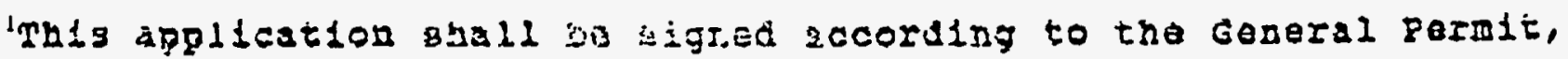
Part V.R., 98 s01I0ws:

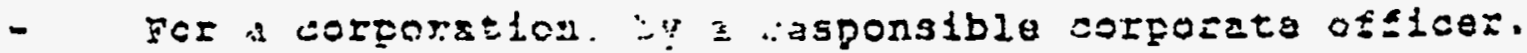

- Tor a partiarshit. :" a zanaral partaer.

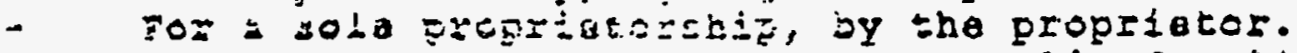

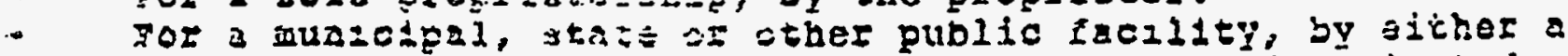
pFincifal axpcutionetices, the arayor, or ranking lectad of:Lیial. 


\section{U.S. Department of Energy \\ Finding of No Significant Impact \\ Diagnostic Instrumentation and Analysis Laboratory \\ Mississippi State University}

AGENCY: U.S. Department of Energy

ACTION: Finding of No Significant Impact

SUMMARY: The Department of Energy has prepared an Environmental Assessment (EA) DOE/EA-1013, evaluating the design, construction, and equipping of the proposed Diagnostic Instrumentation and Analysis Laboratory (DIAL) at Mississippi State University.

Based on the analysis in the EA, the DOE has determined that the proposed action does not constitute a major federal action significantly affecting the quality of the human environment within the meaning of the National Environmental Policy Act of 1969 (NEPA). Therefore, the preparation of an Environmental Impact Statement is not required.

\section{DESCRIPTION OF THE PROPOSED ACTION:}

DOE proposes to authorize Mississippi State University (MSU) to proceed with the detailed design, construction and equipping of the proposed DIAL. Senate Committee Report 101-000 accompanying the Energy and Water Appropriations Act indicated that $\$ 3,976,800$ had been included in DOE FY91 appropriations to assist in constructing and equipping the DIAL at Mississippi State University. A grant was executed with the University in November 1990, and grant funds are available to the University for the limited purpose of performing preliminary studies, including analyses necessary to conduct this environmental assessment. However, under the terms of the grant, the grantee may not initiate construction or take any other action that would affect the environment or 1 imit alternatives until the DOE NEPA process has been completed and DOE has determined that such action should proceed. The proposed DIAL would be designed to address the specific problems and needs associated with large-scale combustion devices and environmental restoration and waste management.

\section{ALTERNATIVES:}

The DOE considered the no action alternative. The impact of DOE not authorizing MSU to proceed with the project would be continuation of current operations under overcrowded conditions. The impact of the proposed action would not occur because MSU could not proceed with the project without DOE support. The University considered another site on its campus for the proposed facility during early planning for the project, but found it would require an access road for which funding was not available. Therefore, this alternative was not considered further, although it was concluded that the impact of the proposed action at the a) ternative site would be essentially the same as at the proposed site. 


\section{ENVIRONMENTAL IMPACTS:}

The EA analyzes the impacts of constructing, equipping and operating the proposed DIAL facility. Areas of potential impact evaluated in the EA included those associated with both the construction and operation of the proposed facility.

Construction impacts evaluated included the effects on sensitive resources (historical/archeological, protected species/critical habitats, floodplain/wetlands, national forests/parks/trails, prime farmland and special sources of water). Also evaluated were erosion, waste disposal, construction equipment air emissions and noise, construction worker impacts on traffic and parking.

Operations impacts evaluated included the effects of waste generation (domestic, sanitary, hazardous), air emissions (criteria, and air toxins), noise, new hires, and accidents.

No significant environmental impacts associated with the proposed construction or operations are anticipated. This finding of no significant impact for the proposed action is based on the following factors which are supported by information and analysis in the EA.

\section{Impacts of Construction/Installation}

None of the categories of sensitive resources cited above occur on or near the site. Air quality impacts would be associated with delivery trucks and on-site construction machinery, and would be low-level and transient. Noise levels would be those conventionaliy associated with daytime construction activities, and would not disturb the adjacent areas, which are not inhabited. Construction traffic would not affect local circulation or parking availability.

\section{Impacts of Operations}

The proposed DIAL facility would bring together the efforts of researchers and laboratories currently located in five different locations. This consolidation of efforts would most likely result in a decrease of all emissions due to the elimination of duplicating activities. The research activities anticipate the addition of less than 15 new employees over a 4 year period, thus illustrating limited growth with a more effective use of resources.

Waste Generation: Domestic and sanitary wastes would meet local requirements and could be readily accommodated by existing municipal services. There would be no production of radiological or mixed wastes associated with the proposed facility. As a "small-quantity" generator of hazardous waste, MSU is subject to the requirements of the Resource Conservation and Recovery Act (RCRA) of 1976. A11 hazardous and toxic waste generated by MSU is disposed of in accordance with all applicable Federal and state regulations and guidelines. Production of hazardous and/or toxic waste by the proposed DIAL would not effect the MSU small generator status. 
Air Quality: Toxic air emissions, mainly from laboratory solvents, would produce insignificant levels of public exposures in relation to threshold 1 imit values defined by the American Council of Government Industrial Hygienists; this is also true for exposure to those working in the proposed facility.

Other Effects: Noise generated indoors or outdoors would be insignificant. Socioeconomic impacts would be small in the scale of overall University economic activity. Accident risk would be very low as evidenced by zero reportable accidents involving hazardous materials at the University in the last ten years. Overall, the incremental impacts of the project are small in relation to the ongoing impact of the University, and do not constitute significant cumulative impacts.

\section{DETERMINATION:}

Based on the analysis in the EA, the DOE has determined that authorization of MSU to proceed with the proposed Diagnostic Instrumentation and Analysis Laboratory does not constitute a major Federal Action significantly affecting the quality of the human environment within the meaning of the National Environmental Policy Act of 1969. Therefore, an Environmental Impact Statement on the Proposed Action is not required.

PUBLIC AVAILABILITY: Copies of this EA (DOE/EA-1013) are available from:

Karen Tenke-White, P.E. Programs and Facility Management Division

U.S. Department of Energy

Chicago Operations Office

9800 South Cass Avenue

Argonne, I17inois 60439

(708) 252-9659

For further information regarding the DOE NEPA process contact:

W. Sedgefield White, NEPA Compliance Officer

Environment, Safety, and Health Division

Chicago Operations Office

U.S. Department of Energy

9800 South Cass Avenue

Argonne, I11inois 60439

(708) 252-2101

Issued in Argonne, I11inois, this $22 \mathrm{nd}$ day of $\mathrm{DeC}_{1} / 994$

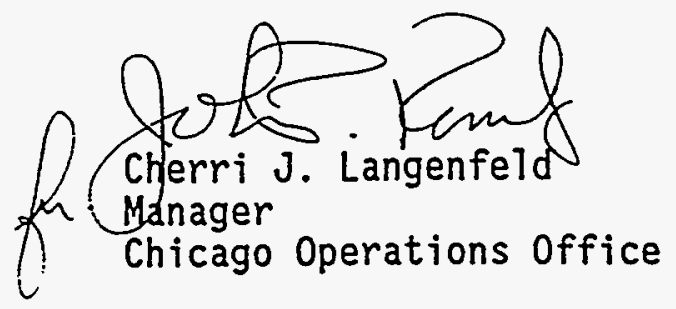

